Article

\title{
Heading to Chaityabhoomi: Pilgrimages of Remembrance
}

\section{Anna Bochkovskaya}

Institute of Asian and African Studies, Lomonosov Moscow State University, Mokhovaya Str. 11, Bldg.1, Moscow, Russia; anna.bochkovskaya@gmail.com

Received: 28 February 2018; Accepted: 2 April 2018; Published: 4 April 2018

\begin{abstract}
This article explores individual and collective pilgrimages to the Mumbai-based cremation ground (samādhi) of Bhimrao Ramji (Babasaheb) Ambedkar (1891-1956), a renowned economist and lawyer, academician and philosopher, political leader and social reformer who dedicated his life to the struggle for rights of the untouchables (Dalits) in India. In October 1956, Dr. Ambedkar together with almost half a million of low-caste followers converted to Buddhism. After Babasaheb's death on 6 December, 1956, his cremation ground became an object of worship for Buddhists and adherents of other religions. In December 1971, on the eve of the 15th year of his demise, the Chaityabhoomi memorial was inaugurated there. A dramatic increase in the number of pilgrims coming from all across India to Dr. Ambedkar's samädhi as well as to other places associated with him has become instrumental in building up Dalits' sites of memory/lieux de mémoire in contemporary India. The growing interest to Chaityabhoomi has also acquired a political dimension in contemporary India.
\end{abstract}

Keywords: Buddhism; pilgrimage; samadhi; Ambedkar; Dalits; Chaityabhoomi; sites of memory

\section{Introduction}

Every year in early December, people from different parts of India flock to Mumbai (Bombay) heading to a park located on the Arabian Sea coast. They arrive well in advance so that in the morning hours of 6 December they can join a queue to the Chaityabhoomi (caitya bhumi) ${ }^{1}$ memorial housing the ashes of their Messiah: this is the day when hundreds of thousands of former untouchables (Dalits) ${ }^{2}$ are willing to pay tribute to the memory of Bhimrao Ramji (Babasaheb) Ambedkar. Since 1956, his cremation place has become a lieu de mémoire, generally defined in the 1980s by Pierre Nora, a French historian, as "any significant entity, whether material or nonmaterial in nature, which by dint of human will or the work of time has become a symbolic element of the memorial heritage of any community" (Nora 1996, p. xvii).

Such sites-a result of the interaction between memory and history-are places "where [collective] memory crystallizes and secrets itself" (Nora 1989, p. 7). They can be represented by any material, symbolic, or functional entities such as museums, libraries, archives, monuments, sanctuaries, festivals, processions, calendars, anniversaries etc. that "capture a maximum of meaning in the fewest signs" (Nora 1989, p. 19). Places of memory emerge in cases when there is a will to remember (Nora 1989, p. 19), so their main task is to maintain memory of a certain group of people.

1 Caitya bhümi means "the land/place of a shrine". Caitya (sacred object: a tree, a cave, a stone etc.) was often used to designate Buddhist shrines in India (Dehejia 1972). Some researchers argue that origins of the term caitya relate to funeral fire (citā) and to structures erected at the latter's place (Khizhnyak 2008, p. 60).

2 Dalit (dalit, "oppressed") is a politicized term currently used for India's lower castes. This term was brought into public discourse and popularized by B.R. Amberkar. For details ref.to (Zelliot 2001). 
The latter is true for Dalits' pilgrimages to the cremation place of Bhimrao Ramji Ambedkar that boast over six decades of history. In a broad sense, such pilgrimages of remembrance or commemorative performances also represent sites of memory being an intangible manifestation of the lower castes' shared past. With a dramatic politicization of the Dalit issue in India since the 1980s and especially in the past decade, the pilgrimages to Chaityabhoomi (as well as to other Ambedkar-related sites $^{3}$ ) have adopted various political connotations thus manifesting their connection with Dalits' shared present and-in some cases-a vision of Dalits' common future, which proves Nora's thesis about the ability of lieux de mémoire to acquire new meanings with time.

This article focuses on the importance of pilgrimages to Chaityabhoomi for constructing Dalits' sites of memory in contemporary India. It draws upon the data coming from my three short field visits to Mumbai in 2013-2017 covering a total of two weeks, and also from informal interviews/talks that I had with low-caste residents of Delhi who had visited the memorable site in Mumbai in the past decade.

\section{Ambedkar's Mahāparinirvāṇa: A Starting Point for Remembrance Journeys}

Dr. Ambedkar (1891-1956) was a renowned economist and lawyer, academician and philosopher, political leader and social reformer, the first law and justice minister (1947-1951) of independent India, and head of the Constitution Drafting Committee (1947-1950). He dedicated his entire life to

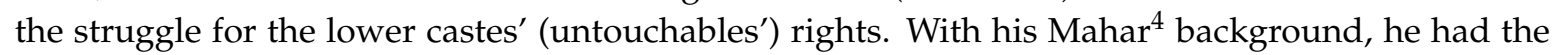
first-hand knowledge about life and problems of the Indian outcastes. Owing to his urge to study and a favorable combination of circumstances, Ambedkar became one of the first untouchables to get access to higher education of superior quality: he studied in prestigious schools and universities of India, the US, Germany, and Great Britain, obtained doctorates in economics and law, and was awarded other degrees. He joined India's politics in the 1920s and soon became an acknowledged leader of the lower castes.

Amberkar aimed at choosing a religion most suitable to care to the needs of the untouchables. He strongly condemned Hinduism as a system that deprived the lower castes of their rights for human life and spent a lot of time researching positive and negative features of Islam, Christianity, Sikhism, and other religions and philosophies. His final choice was in favor of Buddhism, a South Asian-born religion that rejected social inequality both in theory and in practice. On 14 October, 1956, Ambedkar and half a million of his followers embraced Buddhism. The diksha (dikssā), or initiation, ceremony took place in Nagpur (Maharashtra), and the site since then has been called Dikshabhoomi (dīkșā bhümi $)^{5}$.

In less than two months, on 6 December, 1956, Ambedkar passed away in his residence in Delhi. In a few hours, the news was officially broadcast, and many Delhi residents headed to 26 Alipur Road hoping to take a last glance at Babasaheb. The crowd blocked all the passages to his house, and the police took pains to clear the way for cars of India's Prime Minister Jawaharlal Nehru, members of Indian parliament, and other political leaders who came to pay their last tribute to Dr. Ambedkar.

The Buddhist Society of India, an organization revived by Ambedkar in 1955, was in charge of arranging the funeral. In the early hours of 7 December, the body was delivered by airplane to Bombay airport and then taken to Rajagriha (Rājagrhha $)^{6}$-Ambedkar's previous residence-accompanied by a huge crowd. The entire city was in deep mourning: on the funeral day, not a single government institution worked, all enterprises, schools, and colleges were closed, ad spontaneous hartals (strikes) and meetings took place in other cities of Maharashtra as well (Keer 1990, p. 515). In the afternoon a

\footnotetext{
Two other important sites include Dikshabhoomi in Nagpur, Maharashtra, and Rajagriha in Mumbai (see below).

Mahar (mahār) is a low-caste community generally residing in the Indian state of Maharashtra. Formerly, the Mahars were considered untouchables; in present-day India, they are listed as Scheduled Castes.

5 The final years of Dr. Ambedkar's life are depicted in (Rattu 1997).

6 Rājagrha ("king's house/palace") was the name of the Magadha capital where many episodes from the Buddha's life took place.
} 
procession of up to half a million participants headed towards the last rites' site: Dr. Ambedkar was to be cremated according to the Buddhist tradition. ${ }^{7}$

Babasaheb's body was placed on a special platform fixed on top of a truck so that it could be seen from far. The platform was decorated with heaps of flowers and surrounded by candles and incense sticks; a small image of the Buddha was placed near Amberkar's head (Keer 1990, p. 516). The procession was over $3 \mathrm{~km}$ long, and it took its participants over four hours to reach the cremation site (Sangharakshita 1986, p. 118). Those who came to bid farewell to Ambedkar poured petals and placed garlands on the platform, and it was necessary to constantly remove flowers so they would not cover the body. Those who could not make their way through the crowd tried to get on the roofs or trees and tried to see at least some part of the procession from there. Transport in the northern part of Bombay was completely blocked for the day (Keer 1990, p. 516).

The cremation site was prepared near the Hindu crematorium in Dadar-a coastal part of Mumbai. The choice of this place must have been quite difficult. Masselos (n.d.) mentions-without any explanations or comments-that Maharashtra's authorities rejected the proposal to cremate Ambedkar at the seashore near the cremation ground of another national-scale leader, Bal Gangadhar Tilak. ${ }^{8}$ Contemporary Dalit sources do not forget the dissent of Ambedkar's followers with state authorities in this issue. They particularly stress the "caste-based motivation" of this decision: "Since the caste Hindus denied the cremation at Dadar crematorium, a Buddhist-style cremation was organized for him at Chowpatty beach" (Bahujan Samaj Party n.d.). Thus, the final rites took place at a dedicated site close to the Arabic sea coast. Buddhist monks (bhikkhu/bhikșu) read sacred texts, and then Ambedkar's son set fire to the funeral pyre. The Mumbai police saluted Dr. Ambedkar's memory with the "last post" played for the first time in Bombay to a non-official person (Keer 1990, p. 516).

On Ambedkar's cremation day over 500,000 followers converted to Buddhism near his samadhi (samādhi) in Dadar thus fulfilling his last wish: Babasaheb had planned to lead the second mass conversion ceremony on 16 December. One of the bhikkhus conducted the ceremony, and after that Ambedkar's ashes were carried to his former Bombay residence. From there portions of ashes were taken to different places in India including Nagpur, Agra, and Delhi where over 230,000 untouchables embraced Buddhism in December 1956.

The demise of a renowned spiritual and political leader who had virtually become a living god for low-caste Indians had a tremendous emotional effect on his followers everywhere. Vasant Moon, a well-known Dalit activist who has greatly contributed to popularization of Ambedkar's works, described the reaction of millions of his countrymen to the death and subsequent rituals:

The news that Babasaheb's ashes were on the train traveled before us. At every station hundreds of people crowded to see the urn. The sight of people crying uncontrollably was enough to move the heart. Thousands of people thronged to see the urn at Nagpur, and when we emerged from the train [from Bombay to Nagpur] carrying it with us, a wild shout of lamentation came from this mass of people.

During the trip I stored all of the sights calmly in my mind. While viewing the funeral pyre in Mumbai I maintained a calm and cool manner, keeping the words of the Buddha fixed in my mind: 'This body will be destroyed; death is inevitable'. However, hearing the cry from the masses in Nagpur, my heart trembled. Without my being aware of it, tears began to fall from my eyes, and I began to cry along with everyone else. (Moon 2002, pp. 161-62)

7 In India, Buddhists in most cases cremate their dead. It is believed that, after the Buddha's death, his body was given to fire, and the ashes were divided into eight parts or relics and placed in stupas (stüpa). Relic-holding and memorial stupas were built in different places related to the Buddha's life; they became pilgrimage places for Buddhists. For details of the origins, designations, types, and functions of stupas, ref. to (Khizhnyak 2008, pp. 57-72; Harvey 1984, pp. 67-94).

8 Bal Gangadhar Tilak (1856-1920) was a renowned leader of India's national liberation movement. 
The day of 6 December came to be known as Mahaparinirvana (mahāparinirvāna) day for Ambedkar's followers. From that point on, the site in Dadar turned into an object for worship-both for Buddhists as well as for adherents of other religions-becoming a lieu de mémoire with its "fundamental purpose to stop time, to block the work of forgetting, to establish a state of things, to immortalize death, to materialize the immaterial" (Nora 1989, p. 19). Soon, a park was set up around the cremation ground, and on 5 December, 1971, on the eve of the 15th year of Maraparinirvana, the Chaityabhoomi memorial was inaugurated there.

\section{Ambedkar's Shrine: Goal of the Pilgrims}

The two-storey construction erected over Ambedkar's cremation place looks like a stupa (Figure 1): its architecture embodies the main result of Babasaheb's religious and philosophical quest and his practical activities. With Vedic shmashana (śmāśāna) charnel grounds as a prototype (Khizhnyak 2008, pp. 64-68) stupa represents a sort of a burial construction that may contain relics.

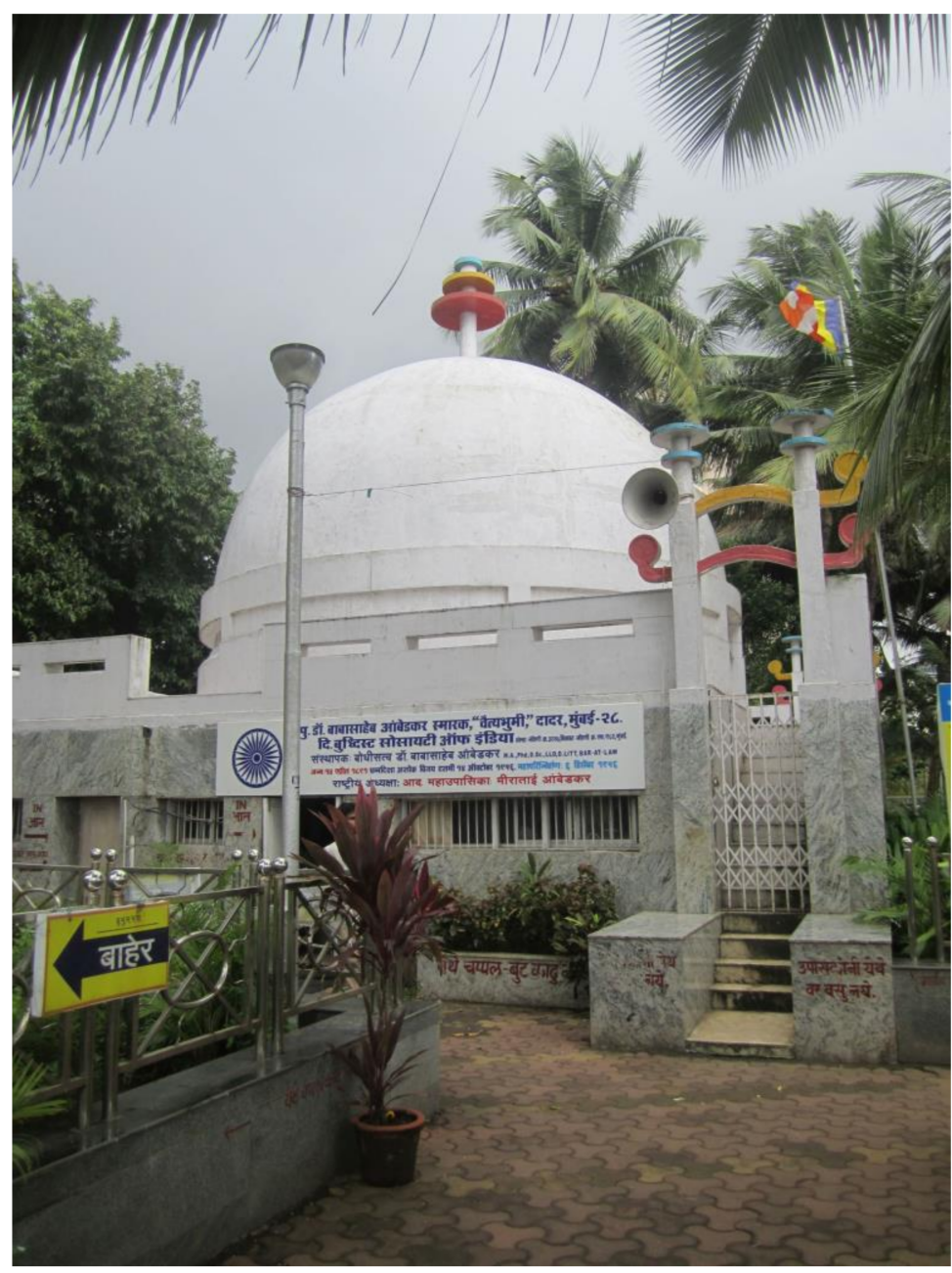

Figure 1. Chaityabhoomi stupa. 
Ambedkar's ashes, the main relic in Chaityabhoomi, rest in a small, square ground-floor room. Sculptures and portraits of Ambedkar and the Buddha ${ }^{9}$ are also there always decorated with bright flower garlands (Figure 2). The second floor-a white marble cupola-houses a rest hall for bhikkhus; the cupola is surrounded by a square-shaped railing and topped by a chatra (a pillar carrying three umbrella-like disks). Similarly to most Buddhist shrines, the stupa is far from being pompous, and its design is quite simple.

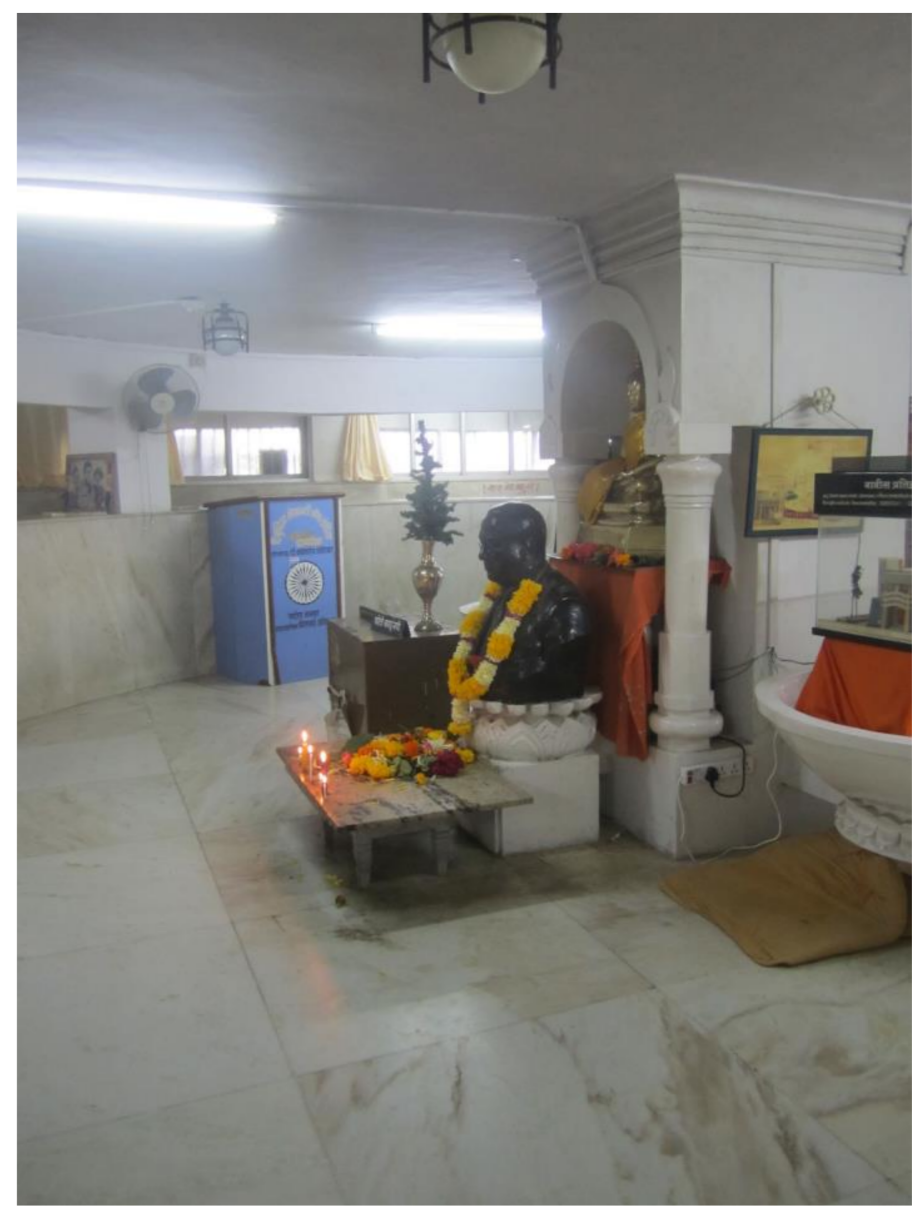

Figure 2. Inside the Chaityabhoomi stupa.

Torana (torana) gateways are located to the North and South of the stupa; they are decorated with reliefs depicting people, animals, and flowers and are topped with the dharmachakra, an ancient image symbolizing Buddha's teaching (Figure 3). The memorial boasts elements typical for ancient stupas of Central and North-Western India, while the reliefs on the gates resemble images from Central and Southern India (Tartakov 1990, pp. 412-13).

9 Images of Babasaheb and the Buddha often go together. Sculptures or portraits of Ambedkar usually follow the same pattern: he is depicted wearing a European-style suite and thick round glasses, and carrying a book, "The Constitution of India." 


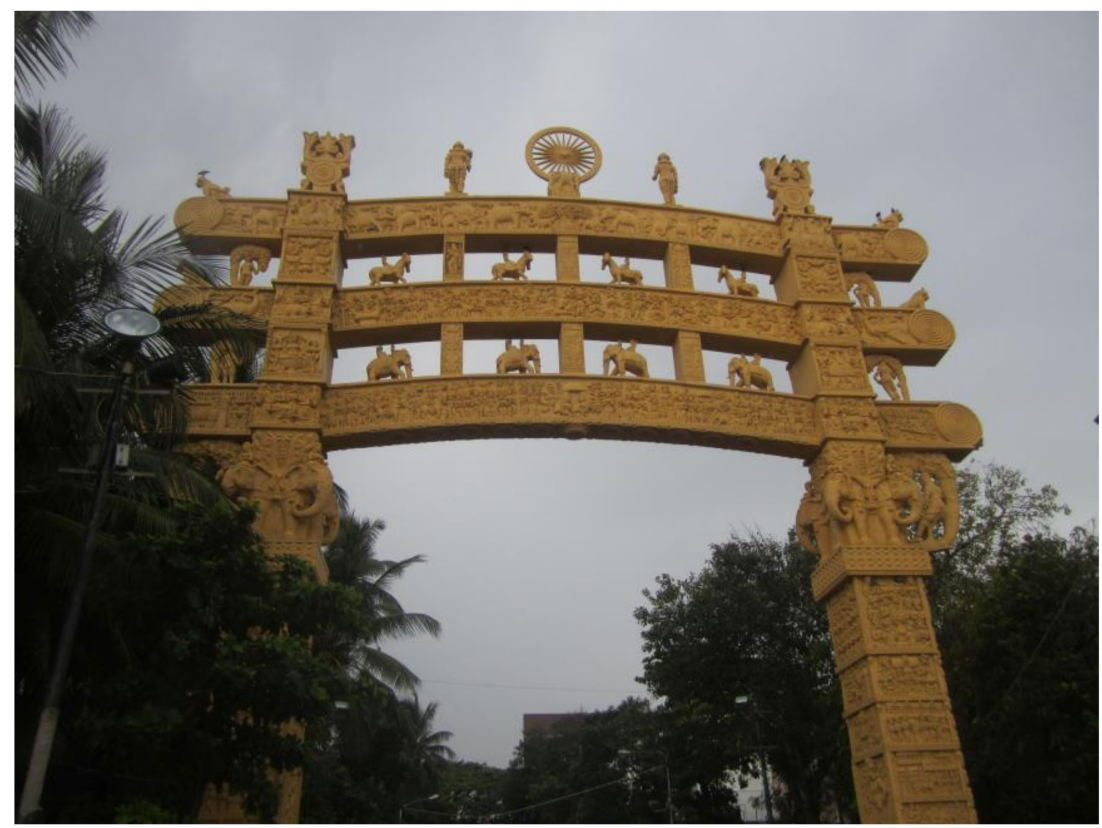

Figure 3. Torana gateway.

In the early 2000s, another symbol of Buddhism and Indian statehood-a copy of the Ashokan pillar from Sarnath ${ }^{10}$ - was placed on a vast terrace facing the Arabian Sea. Recently, in order to expand the park, Mumbai municipal authorities bought 12 acres of land from the National Textiles Corporation owning lands nearby and proposed the Chaityabhoomi development project supposed to be funded by the Maharashtra government. The project currently estimated at over Rs 7 billion (700 crores) includes stupa's reconstruction into to a five-storey building, construction of library, a parking lot, a number of viewing points, a replica of a historic pond in Raigad, and a 350-foot statue of Dr. Ambedkar (Venkatraman 2017).

Authorities of Maharashtra and Mumbai have been paying great attention to the development of Chaityabhoomi since the number of visitors and pilgrims keeps growing from year to year. Ambedkar's followers and admirers visit his samadhi on Ambedkar Jayanti Day (14 April), on the conversion day (October 14), and on the memory (punyatithi) day (6 December). Ambedkar Jayanti is the government holiday of India, but the maximum number of those willing to visit Dadar falls on the Mahaparinirvana day ${ }^{11}$. In December 2016, the government of Maharashtra approved "A" class pilgrimage and tourist destination status for Chaityabhoomi, which is supposed "to pave way for the overall development of the place of historic importance" (PTI 2016).

The official component of annual celebrations in Chaityabhoomi on 6 December features visits of India's and Maharashtra's authorities, politicians, and Babasaheb's descendants who place garlands to the images inside the memorial. This ceremony brings about a short pause in the endless stream of visitors forming a several-kilometers queue from the early hours to enter the stupa and take the traditional darshan: they are willing to see the holy ashes, touch Ambedkar's and the Buddha's images, and offer them candles and flowers as gifts.

On 6 December, the entire area around Chaityabhoomi hosts open-air celebrations-something seemingly incompatible with the tragic meaning of the date. The feeling of festivities is largely a result of the crowd effect, i.e., the mutual emotional "recharging" of a huge number of the visitors.

10 During Ashoka's rule (III BC), Buddhism was wide-spread in India. The upper part of the famous Sarnath pillar with four lions can be seen in the official emblem of India.

11 In December 2016, the number of Ambedkar followers who came to Dadar for the 60th Mahaparinirvana Day was estimated at over 800,000 (Sutar 2016). 
Besides, according to the results of recent interviews, most of the pilgrims do not perceive Ambedkar's memory day as a tragic date (Jadhav 2007, pp. 87-88). The "fairground mood" is also boosted by the fact that the entire park premises look like a bazaar: petty traders sell flower garlands, candles, incense sticks, souvenirs, CDs, and all sorts of printed matter featuring two Dalit icons-Dr. Ambedkar and Buddha. Very popular are calendars with the New Year beginning on 6 December or 14 April; in such calendars the chronology is tied up to Bhīmābda or Buddhābda (Ambedkar's or the Buddha's date of birth, respectively) along with the Gregorian style. ${ }^{12}$ (Figures 4 and 5).

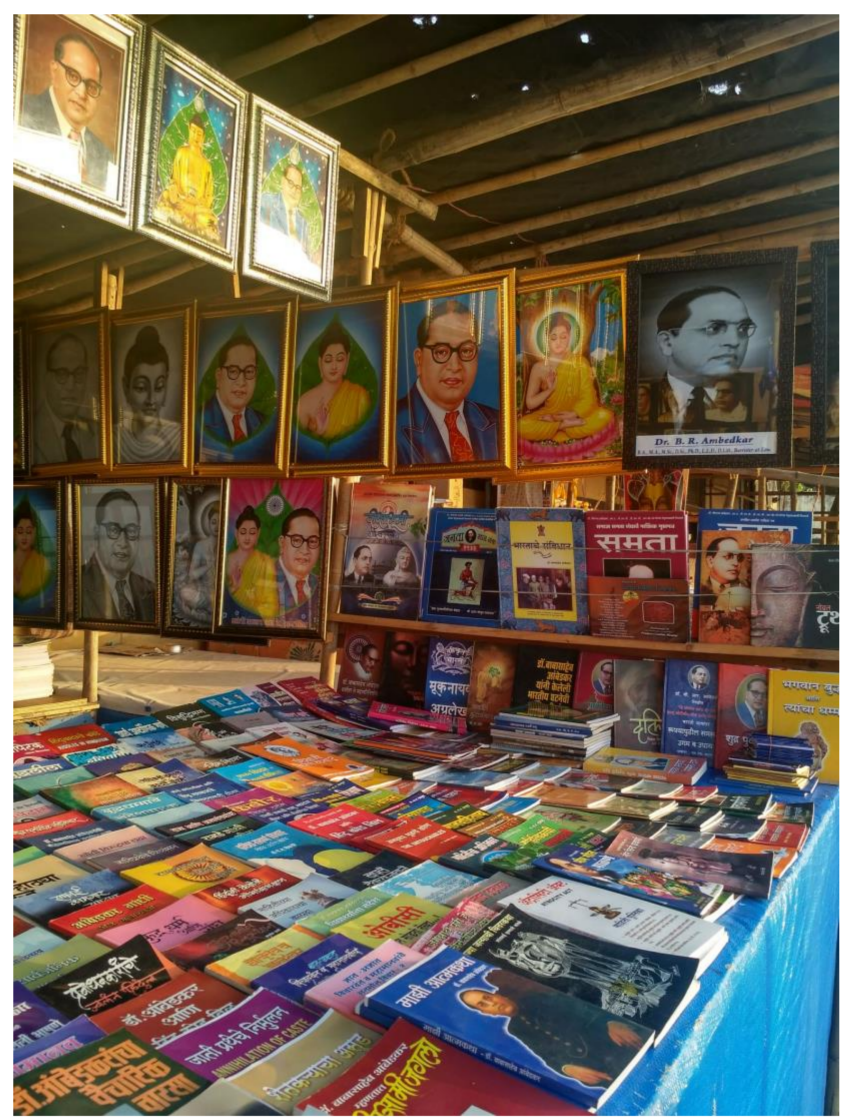

Figure 4. Ambedkar and Buddha posters and books.

12 Such Ambedkar- or Buddha-centered calendars themselves can be perceived as lieux de mémoire: (Nora 1989, pp. 19-20) discusses the role of the French Revolutionary calendar $(1792-1805,1871)$ as a place of memory and notes that "as a calendar, it was designed to provide the a priori frame of reference for all possible memory while, as a revolutionary document, through its nomenclature and symbolism, it was supposed to 'open a new book to history,' as its principal author ambitiously put it, or to 'return Frenchmen entirely to themselves', according to another of its advocates." In a similar way, "returning" Ambedkar's followers/pilgrims "to themselves" by using dedicated calendars and other images is also part of the general framework of commemorative pilgrimages to Chaityabhoomi. 


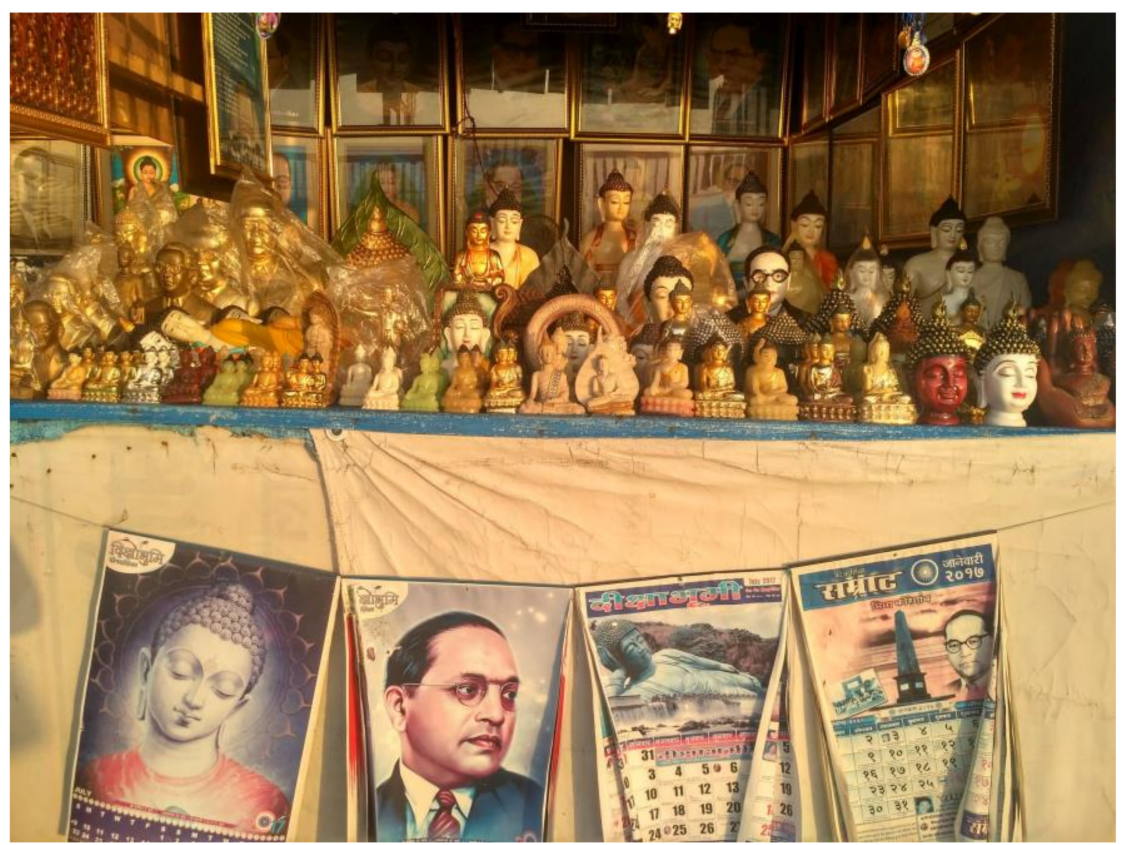

Figure 5. Ambedkar and Buddha calendars and images.

The annual December assembly of Ambedkar's followers is a matter of big administrative and financial concern for Mumbai municipal authorities. Special platforms and tents are set up to accommodate and provide night shelter to thousands of pilgrims who come from distant places and are willing to spend several days in Dadar. The site is equipped with water and electricity supply lines, and washrooms. Besides, the presence of large crowds of visitors in the central part of Mumbai needs special security precautions. Huge assets are required to ensure safety in a park area that allows the passage of over one million visitors in a single day. In order to control the situation and be ready to react anytime, the municipal and state authorities have recently begun to employ State Reserve Police Force, Riot Control Police, Rapid Action Force, and other special-purpose units.

The necessity to engage personnel from different law-enforcement agencies also comes up from the fact that since the 1990s, all such agencies in Maharashtra and beyond have been staying on alert on the eve of 6 December on the watch for possible Hindu-Muslim clashes. On that very day in 1992, Babri Masjid in Ayodhya was demolished by Hindu fundamentalists ${ }^{13}$ thus triggering religious violence all across India including the multiconfessional Bombay/Mumbai. Being afraid of a possibility of such violence in the megalopolis $(22 \mathrm{mln}$ ) with a potentially dangerous ratio of Hindu and Muslim population (67 and 18.5\%, respectively), Mumbai's authorities aim at playing safe. This is why security precautions in the Chaityabhoomi area increase from year to year.

\section{Site of Memory, Pilgrimages, and Politics}

As mentioned above, the lower castes' constantly growing attention towards the Ambedkar memorial has been stipulated by the dramatic politicization of the "Dalit issue" in the recent decades. On the one hand, over six decades since independence have brought about positive changes in the life of Dalits owing to the positive discrimination policy pursued by the Indian government in the

13 The ongoing Hindu-Muslim conflict in connection with the place of Rama's birth (Rām Janambhūmi) and Babur's Mosque (Babri Masjid) build there by Muslim conqueror Babur in the XVIth century was boosted by Hindu communalists in the 1980s. The media has been throwing out suggestions that Hindu communalists had deliberately timed this action to Ambedkar's memory day to threaten the adherents of other faiths. See for example (Chamadia 2016; Tulasi 2016; Yadav 2009). 
fields of education, government service, and politics. ${ }^{14}$ At the same time, a majority of Dalits continue to languish in poverty. The de-facto deprivation of rights of most vulnerable social groups, their extremely low literacy level, the increasing violence toward Dalits, and their victimization-all these present-day realities remain in focus of different political forces. Besides, not a single political party can ignore the Dalit factor due to the quantity of the former untouchables (over $200 \mathrm{mln}$ ) in present-day India. To this end, Maharashtra is no exception with its political setup largely determined by the electoral behavior of Scheduled Castes comprising over 10 percent of the state's population. ${ }^{15}$

For Dalits, Ambedkar's image as that of a successful political leader boasting a consistent stand on key issues of economic and political liberation of the outcastes is of special importance. However, equally important is his image of a national-scale leader who insisted that lower classes should unite to achieve their goals (Jaffrelot 2005, pp. 143-60). After Babasaheb's demise, the lower-castes movement was regionalized and actually split up between the states: the new generation of politicians who took his place focused on local goals and targets as well as on the interests of local (caste- and ethno-based) groups of Dalits. The feeling of belonging to a single nation-wide community-something that Dalits experienced during the life of Dr. Ambedkar largely owing to his efforts-began to fade away.

Pilgrimages to Chaityabhoomi together with hundreds of thousands of like-minded people to a certain extent revive the former feelings, which eventually means that Dr. Ambedkar's site of memory physically embodied in his ashes as an object for worship continues to play the integrating role throughout decades. Typical is the following comment of a visitor in Dadar when asked about reasons for her arrival to Chaityabhoomi: "I live in a village not far [from Mumbai] and I come here every December. Sometimes, I also come on other dates, in spring. This time I am here [for a holiday] with my family. I want to show this place to my children. They know who Babasaheb was, but they must learn more about him: he was the one who stood for the poor, for the Dalits. He wrote the constitution for all our people" (Ambedkar 2016).

For the lower castes, Dr. Amberkar's samadhi is both a sacred place accumulating memory about the god of the Dalits and an important political symbol. Chaityabhoomi acts as a starting place for demonstrations and protest marches of municipal or state level. Ambedkar's memory day-as any regular mass action -is a perfect opportunity for political organizations (first of all, for the Republican Party of India, $\mathrm{RPI}^{16}$ ), to publicize itself, and diversify the outreach through the commemorative performances. Posters and banners with party symbols, distribution of leaflets and booklets, and RPI activists wearing traditional blue Jai Bhi $m^{17}$ bandages-all this visual matter immensely contributes to the party image. Besides, the activists contribute to keeping order in Dadar as they help seeking those lost in the crowd, arrange the queue to the memorial, and distribute water and food etc.

Other political agents both in and outside Maharashtra also use every opportunity to exploit their demonstration of reverent attitude to Ambedkar's memory and to millions of Dalits. Different parties continue to raise the question of renaming the Dadar railway station to Chaityabhoomi. At varying times this idea was put forward by the Shiv Sena and the Bharatiya Janata Party and also by their political antagonists, i.e., the Indian National Congress and the Nationalist Congress Party; politicians representing different fractions/splinter groups of the Republican Party of India did not either keep out. It goes without saying that this suggestion is of no practical use, and not a single party has forwarded an official suggestion to Delhi ${ }^{18}$ in favor of renaming the station, but the politically attractive issue has successfully been used for almost two decades during election campaigns and debates (Joshil 2011; Rao 2016).

14 Provisions concerning the special status of these and some other deprived categories were added to the Indian Constitution at the insistence of and all sorts of printed matter featuring two Dalit icons. Ambedkar.

15 In 2001, Scheduled Castes in Maharashtra numbered $10.5 \mathrm{mln}$ out of $96.7 \mathrm{mln}$ of the state's population (Census of India 2001, p. 1). In 2011, this figure went up to $13.3 \mathrm{mln}$ (out of $112.4 \mathrm{mln}$ ) (Census of India 2011).

16 The Republican Party of India was founded in 1957. Its program and other documents had been elaborated by Dr. Ambedkar.

17 Jai Bhìm (Long live Bhim[rao]!) is a salutation of Mahar Buddhists that has become a political slogan of the Dalits.

18 The renaming issue is within the competence of India's central authorities. 


\section{Conclusions}

With the passing of time, pilgrimages of Ambedkar's followers to his Samadhi-a major place of memory-took on new dimensions: grief and sorrow that were central in pilgrims' feelings and emotions shortly after Babasaheb's demise receded into the background, while other sentiments began to dominate. Along with the unfading gratitude to the leader of the oppressed, they currently include a "recycled" sense of belonging to a vast Dalit community whose influence keeps growing in all spheres in India, especially in politics, and contributes to building up the self-assertion of lower castes. Consequently, the Dalits' pilgrimages to Chaityabhoomi have assumed an additional semantic content: when visiting Dadar in the coastal part of Mumbai to commemorate Bhimrao Ramji Ambedkar (which remains the primary goal), Babasaheb's followers are implicitly "remembering their [historical] journey from subordination to emancipation" (Narayan 2017). This signifies that Ambedkar's memorial as a lieu de mémoire turns in on oneself (Nora 1989, p. 20). Thus, both the remembrance pilgrimages and the Chatyabhoomi site per se are acquiring new meanings in the cycles of memory.

Conflicts of Interest: The author declares no conflict of interest.

\section{References}

Ambedkar, B. R. 2016. Personal communication in Dadar, January 20.

Bahujan Samaj Party. n.d. Bharat Ratna Dr. Bhimrao Ramji Ambarkar (Babasaheb). Available online: http: / / bspindia.org/bhimrao-ambedkar.php (accessed on 15 January 2018).

Census of India. 2001. Maharashtra: Data Highlights: The Scheduled Castes. Available online: http:/ / censusindia. gov.in/Tables_Published/SCST/dh_sc_maha.pdf (accessed on 15 January 2018).

Census of India. 2011. Maharashtra: Population Growth: Levels and Trends. Available online: http: / / censusindia.gov.in/2011-prov-results/data_files/maharastra/7-\%20Chapter\%20-\%204.pdf (accessed on 15 January 2018).

Chamadia, Anil. 2016. Babri Masjid \& Ambedkar: How 6 Dec can be a day to mark Dalit-Muslim unity. Catchnews. Available online: http:/ / www.catchnews.com/india-news/babri-masjid-ambedkar-how-6-dec-can-be-aday-to-mark-dalit-muslim-unity-1481035089.html (accessed on 15 January 2018).

Dehejia, Vidya. 1972. Early Buddhist Rock Temples. A Chronological Survey. London: Thames and Hudson.

Harvey, Peter. 1984. The Symbolism of the Early Stūpa. Journal of the International Association of Buddhist Studies 7: 67-94.

Jadhav, Praveen. 2007. Ambedkar's People in India: With Reference to "Chaityabhoomi". New Delhi: Rajat Publications. Jaffrelot, Christophe. 2005. Dr. Ambedkar and Untouchability: Analysing and Fighting Caste. London: Hurst \& Co.

Joshil, Prakash. 2011. NCP yet to finalize stand on renaming Dadar station. The Times of India. Available online: https:/ / timesofindia.indiatimes.com/city/mumbai/NCP-yet-to-finalize-standon-renaming-Dadar-station/articleshow / 8670849.cms (accessed on 17 January 2018).

Keer, Dhananjay. 1990. Dr. Ambedkar: Life and Mission. Mumbai: Popular Prakashan.

Khizhnyak, Olga. 2008. Stupa: Nachalo Formirovaniya Buddiyskogo Kulta. St Petersburg: St Petersburg University. (In Russian)

Masselos, Jim. n.d. The Life of Dead Bodies. Corporality and Memory in Pre-Independence Bombay (Manuscript). Sydney: University of Sydney.

Moon, Vasant. 2002. Growing Up Untouchable in India. A Dalit Autobiography. New Delhi: Vistaar Publications.

Narayan, Badri. 2017. Memory of 6 December holds high political and mobilization potential. Livemint. Available online: http:/ / www.livemint.com/Opinion/3MoBWQbHqzjV3rRgUfszSJ /Memory-of-6-December-holdshigh-political-and-mobilization-p.html (accessed on 15 January 2018).

Nora, Pierre. 1989. Between Memory and History: Les Lieux de Mémoire. Representations 26: 7-24. [CrossRef]

Nora, Pierre. 1996. Preface to the English-Language Edition. In Realms of Memory: Rethinking the French Past. Edited by Pierre Nora. New York: Columbia University Press, pp. xv-xxiv.

PTI. 2016. Maharashtra Government Approves 'A' Class Pilgrimage Status for Chaitya Bhoomi. The Indian Express. Available online: http:/ /indianexpress.com/article/india/maharashtra-government-approvesa-class-pilgrimage-status-for-chaitya-bhoomi-4406696/ (accessed on 15 January 2018). 
Rao, Shashank. 2016. Mumbai: State Plans to Change Names of Six More Railway Stations. Mid-day.com. Available online: http:/ / www.mid-day.com/articles/mumbai-raliway-station-oshiwara-ram-mandir-elphinstoneprabhadevi-mumbai-news/17837185 (accessed on 15 January 2018).

Rattu, Nanak Chand. 1997. Last Few Years of Dr. Ambedkar. New Delhi: Amrit Publishing House.

Sangharakshita. 1986. Ambedkar and Buddhism. Glasgow: Windhorse Publications. Available online: https: / / ru.scribd.com/doc/54497329/Ambedkar-and-Buddhism (accessed on 15 January 2018).

Sutar, Kamlesh Damodar. 2016. Lakhs Pay Homage to Dr B.R. Ambedkar in Mumbai on His 60th Anniversary. India Today. Available online: https://www.indiatoday.in/india/story/dr-br-ambedkar-babasahebconstitution-mumbai-death-anniversary-mahaparinirwan-diwas-chaityabhoomi-356036-2016-12-06 (accessed on 17 January 2018).

Tartakov, Gary Michael. 1990. The Rise of a New Buddhist Imagery. Art Journal 49: 409-16. [CrossRef]

Tulasi, Praveen. 2016. 'December 6th: Ambedkar-Babri Masjid Demolition and Dalit'. Round Table India. Available online: https:/ / roundtableindia.co.in/index.php?option=com_content\&view=article\& $\mathrm{id}=8895$ :december-6th-babri-masjid-demolition-and-dalit\&catid=119:feature\&Itemid=132 (accessed on 15 January 2018).

Venkatraman, Tanushree. 2017. Cost of constructing Ambedkar memorial, at Mumbai's Indu Mills, likely to rise. Hindustan Times. Available online: https://www.hindustantimes.com/mumbainews / cost-of-constructing-ambedkar-memorial-in-mumbai-s-indu-mills-likely-to-rise/storynxTkUzYWDJfCywed7mBn2J.html (accessed on 15 January 2018).

Yadav, Ashok. 2009. Babri Mosque Demolition: Why on December 6? Countercurrents.org. Available online: http:/ / www.countercurrents.org/yadav210209.htm (accessed on 15 January 2018).

Zelliot, Eleanor. 2001. From Untouchable to Dalit. Essays on the Ambedkar Movement. New Delhi: Manohar.

(C) 2018 by the author. Licensee MDPI, Basel, Switzerland. This article is an open access article distributed under the terms and conditions of the Creative Commons Attribution (CC BY) license (http://creativecommons.org/licenses/by/4.0/). 